International Journal of Applied Economics, Finance and Accounting

ISSN 2577-767X

Vol. 5, No. 2, pp. 39-47.

2019

DOI: $10.33094 / 8.2017 .2019 .52 .39 .47$

(C) 2019 by the authors; licensee Online Academic Press, USA

\title{
Determinants of Export Service in Selected West African Countries
}

\author{
Ignatius Abasimi ${ }^{1^{*}}$ \\ Long Vorlak ${ }^{2}$ \\ Agus Salim ${ }^{3}$ \\ Xuan $\mathrm{Li}^{4}$
}

${ }^{2,2,4,4}$ School of Economics, Northeast Normal University, Changchun, Jilin, China

'Email:abasimiignatus@gmail.com

'Email: vorleaklong@yahoo.com

${ }^{3}$ Email:ags1.92@nenu.edu.cn

Licensed:

This work is licensed under a Creative

Commons Attribution 4.0 License.

Keywords:

Export service

Foreign direct investment

Real exchange rate

West Africa.

Accepted: 25 September 2019

Published: 9 October 2019

\begin{abstract}
This study empirically tries to investigate the determinants of export service in selected West African countries (Ghana, Benin, Côte d'Ivoire, Gambia, Mali, Niger, Sierra Leone, Togo, Nigeria and Burkina Faso). The study adopted the export demand function introduced by BahmaniOskooee (1986) with little additions and modifications of variables based on the reviewed literature. It was discovered from the empirical results that the value added by the services has no impact on service export. However, variables such as foreign direct investment, communication facilities, real exchange rate, and foreign income level possesses a significant robust impact on export trade in services in the selected countries. These countries should therefore widen their opportunities to strive in exporting services worldwide. This can be materialized by exploiting their potentials with relative competitiveness and reasonable negotiations in the global export markets.
\end{abstract}

Funding: This study received no specific financial support.

Competing Interests: The authors declare that they have no competing interests.

\section{Introduction}

In this $21^{\text {st }}$ century, service exports are growing more rapidly as each year, month and day passes. Service export are services provided by inhabitants in one country to companies, households or firms from another country. In recent times different countries and corporations are profiting greatly from export services, and some predictions ensure that these exports will nurture swiftly. Service exports are an important emerging trend in global trade. Many traditional manufactured exports are increasingly containing technologies that require installation, troubleshooting, maintenance and repair. Recent statistics shows that exports of world commercial services have recorded relatively higher growth (6\%) compared to trade in goods (2\%) in 2013 (World Trade Organization (WTO), 2014). Service sector account for the largest share in some developed countries GDP's, as compared to developing countries, especially in some West African countries (the service sector in these countries mostly provide internal services with only a few of them been exported), this is because more attention has been placed on trade in goods which has grown faster than trade in services in these economies.

Globally, as of 2008, the EU has the highest share of total world trade in services (26\%). The list consists of the United States (17.3\%), Japan (5.8\%), China (5.6\%), India (3.5\%) and South Korea (3.1\%). The United States is one of the top economies with the highest share of service trade. Among the US service exports, China has the highest average share (16.44\%), followed by non-OECD economies (13.11\%), the United Kingdom (12.03\%) and the North American Free Trade Area 11.92\%, Sandeep (2011).

Organization for Economic Co-operation and Development (OECD) (2002) noted that, the rapid growth of trade services is closely linked to the world economic globalization and technological advances in information and communication services. Though world growth has increased, the share of trade in services in terms of overall value is much lower. In the year 2013, the value of world trade in goods exceeded $\$ 18.5$ trillion, while the trade in services was approximately $\$ 5$ trillion (UNCTAD, 2014). At the same time, in terms of share, trade in services accounts for about $20 \%$ of global trade (WTO, 2010). This development has had a more influence on countries that lay emphasis on generating extra income from the external sector, particularly through service exports. 
According to United Nations Conference on Trade and Development (UNCTAD statistics), the global share of developing exports has increased from 23\% to 30\% from 2005 to 2017 as displayed in Figure 1. Though trade in services generally grew faster than commodity trade, it is clear that growth rates are still quite dissimilar across major economic groups. For both developing economies and economies in transition, export of services in these economic sectors has increased since 2005. While export growth has often been higher for developed countries since 2005, export growth in developing and transitional economies or countries has generally begun to grow higher in 2011.

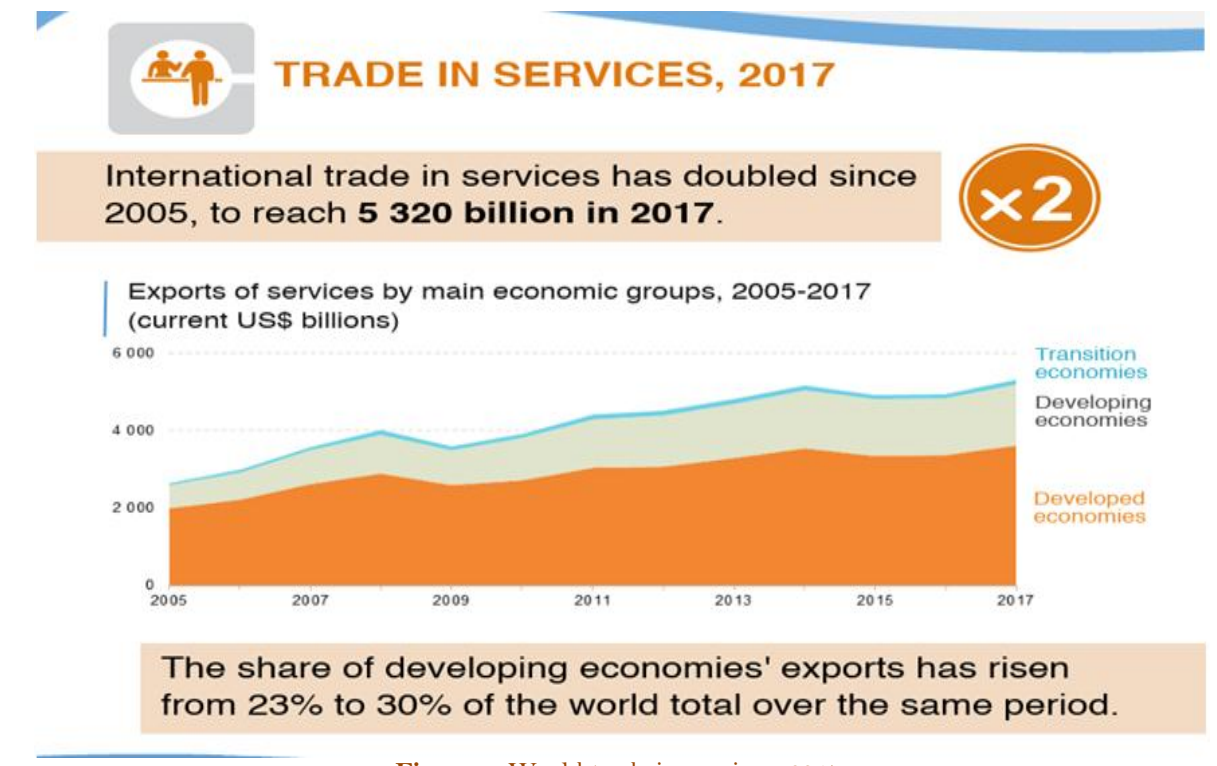

Source: UNCTAD.

Figure-1.World trade in services, 2017

Notwithstanding this stunning performance, the presence of developing countries in the global market as a service provider is generally limited, where service exports in international markets or their controls are largely supplied by developed countries. This enlightens, to some extent, why most developing countries have been unable to account for their services while maintaining surplus in their goods account. This makes it imperative for developing countries to find ways to increase their influence of service exports and ultimately expand their existence in the international services market. It has been noted that reforms in the export services sector can contribute significantly to the performance of the sector and positively distress the overall development of nations (Hoekman, 1996). Although services contribute more than 50\% of GDP in most developing countries, the role of the sector on the external front has not been very satisfactory, despite positive progress, especially in the case of developing countries in West Africa.

Service export in Africa has been on the increase over the past few decades, through this lens, trade has been facilitated through the flow of goods, services, investment and knowledge required to produce products in multiple settings - leading to the so-called Intellectual Property Association for Trade and Investment. Trade in services is a single channel that facilitates and coordinates the necessary communications to increase participation and enhance competitiveness within these chains. Indeed, strengthening the competitiveness of the service sector and strengthening the country's linkages with the global economy is now a necessary condition for the continued economic development of Africa (see Africa Competitiveness Report (2015)).

Notwithstanding the above, the progressively vital role of services in African economies is challenging long-term economic development theories. For years back, the first step in getting rid of poverty has been to increase agricultural productivity, and then growth in manufacturing. Traditionally, a larger share of services in an economy is considered a future destination, which is the area of comparative advantage in more advanced economies. In the past few years, Africa has been developing along different tracks. Throughout the continent, the share of agriculture in gross domestic product (GDP) has fallen, while manufacturing, rather than theoretically expected growth has stagnated. In contrast, the service sector's share of employment and total GDP is increasing driving value-added and providing key inputs to other economic activities in the continent and its subregions, especially West Africa (Africa Competitiveness Report, 2015).

Nevertheless, most traditional trade theories have stipulated and outlined some vital factors that influence international trade and the numerical contributions of international trade on economic development. However, numerous empirical studies recently focused on trade in goods and other factors of bilateral trade. Even with the growing importance of the service sector and the rapid internationalization of services, few studies have examined issues related to service trade and service exports. Current publications on services focus primarily on the impact on service sector growth, the determinants of trade in services and their impact on foreign 
direct investment growth (see (Alege \& Ogundipe, 2015; Dash \& Parida, 2013; Lorde, Francis, \& Drakes, 2011)). Therefore, this study aims to fill the gap by exploring the determinants of service exports in selected developing West African countries. In addition, this study supplements the scanty existing literature on determinants of service exports and trade in services especially with respect to group of countries. The results of this study may have important policy implications for Africa developing economies as most of these countries are now turning their economies into services or technologically-based economies as well as liberalizing services in regional and multilateral trade patterns.

\section{Literature Review}

The classical and modern trade theories have highlighted the economic importance of trade and international movement of goods and service on national welfare and economic growth. Base on this background, most empirical studies has developed and in trying to extrapolate the contributions of international trade on economic advancement, employed different methodologies and typologies to estimating these effects on economic growth (see (Barry, Park, \& Shin, 2012; Frankel \& Romer, 1999)). This section therefore offered a more comprehensive literature review on general export service determinants.

Grunfeld and Moxnes (2003) applied the model of gravity to the dual export of services and foreign direct investment flows using data from the Organization for Economic Co-operation and Development (OECD). The regression includes the level of GDP and GDP per capita in importing and exporting countries, distance between them, dummy variable if both are members of the Free Trade Area (FTA), which is a measure of corruption in the importing country and the Trade Restriction Index (TRI11) which also measure barriers to trade in services in the importing country. Their results suggested that the effects of the ordinary gravity model found in commodity trade studies also apply to service. Trade between the two countries is positively related to its size and is negatively related to its distance between them and barriers to services in the importing country. They found that having an FTA is not great in the case of services.

Kimura and Lee (2004) use a combination of OLS and constant time effects to compare traded in goods with that in the services in the preparation of gravity model. As is the case with Grunfeld and Moxnes (2003) use OECD statistics on trade in services, Kimura and Lee (2004) include the traditional Gravity model variables such as adjacent and language puppets. They used a measure of remoteness as a regressor and discovered distance among trading partners to be more important in the trade of services than trade goods they suggested that this involves high transport costs for services but fails to deliver any reason why this may be the case. The existence of free trade agreements, on the other hand, was found to possess positive impact on trade, which runs counter to the results of Grunfeld and Moxnes (2003). The authors argue that even though most FTAs do not explicitly cover services, their Presence may facilitate the process indirectly.

Anderson and Eric (2003) criticize McCallum and Wolf and argue that their results are partly because of the deletion of the bias variable. According to the authors, McCallum Wolf failed incorporating the term multilateral resistance and thus its models have no theoretical justification. Failure to integrate the average trade barrier in the model leads to overstating bilateral trade of close trading partners. In order to obtain unbiased results, one needs to use a general equilibrium model before and after removing the trade barrier because in this way the effect on the medium trade barrier can be adjusted. However, the results indicate that national borders reduce bilateral trade by 20 to $50 \%$. These estimates are much smaller than those in previous research, such as John (1995). Due to the aforementioned bias above, the study contributes to the fact that McCallum \& Wolf) considered the impact of borders on the proportion of national trade to and from international borders is considered and its impact is intrinsically great in small countries.

Francois, Hoekman, and Woerz (2007) estimated the openness of the service sector in the trade and foreign direct investment with panel datasets of some comprehensive service sectors in 178 countries. The study developed a two-stage estimator that is appropriate for available balance of payments service trade data lacking bilateral specifics. The result is a series of comparable, detailed trade and foreign direct investment limited indices covering time, sector and country levels. The study's estimates of service sector openness and related trade cost equivalents remain unchanged for domestic regulatory structure of the OECD.

Brandicourt, Schwellnus, and Woerz (2008) investigates the potential of trade in services in two steps using gravity model to study the sample of bilateral service trade flow in special service categories in 65 countries from 2000 to 2005. Specifically, the Austrian economy has been found to have substantial potential undeveloped trade in services. Although Austria's travel services are reaching their goals potential, there is still plenty of room for commercial service exports.

The study of Copeland and Mattoo (2008) noted that trade in services is different from commodity trade in two respects. First, trade in goods involves transporting goods from one country to another, but in terms of trade in services, cross-border trade is not the most important way of conducting international transactions. Second, services are often highly regulated, and many types of services are provided or produced by regulated monopolies. Barriers to trade in services stem from domestic regulations, which often have the dual purpose of responding to market failures (such as the quality standards of medical practitioners) and protecting local suppliers from foreign competition. Qasenivalu (2008) pointed out that since trade in services is imperceptible, services are not considered as trade, and they are not involved in the preliminary negotiations of the 1947 
General Agreement on Trade and Tariffs (GATT). However, in the mid-1980s, the service industry was recognized as the main body of trade and was first included in the 1986-1993 world trade organization (WTO) Uruguay Round of Trade Negotiations. According to the General Agreement on Trade in Services (GATS), trade in services is divided into four supply models (Mattoo \& Stern, 2007).

Based on significant advances in information and communication technologies and e-commerce, Freund and Weinhold (2004) made an effort to use detailed data from 31 countries and 14 industries to determine whether the Internet has had a significant impact on actual international service delivery. They estimated the general model of trade in services across countries and investigated whether Internet penetration data, measured by the number of Internet hosts in a country, is statistically significant. Overall, the findings confirm that the Internet is related to the growth of trade in services. After controlling for changes in GDP and exchange rates, the results showed that foreign Internet penetration increased by $10 \%$, export growth rate increased by about 1.7 percentage points, and import growth rate increased by 1.1 percentage points.

Siti, Shivee, and Normaz (2017) adopted the Bahmani-Oskooee (1986) export demand function to estimate the determinants of service exports in some selected Asian countries (China, Hong Kong, South Korea, India, Iran, Indonesia, Malaysia, Philippines, Singapore, Thailand, Kuwait, Saudi Arabia and Turkey) from 19852012. The empirical results pointed out that the added value to export of service, exchange rates, foreign income, services and communications facilities, foreign direct investment (FDI), may affect service exports from the selected developing Asian countries. Their study indicated in the conclusion remarks that these countries may have the opportunity to strive globally through export services, provided they can develop and enhance their potential by focusing on important and vital export service indicators.

Pravakar, Ranjan, and Prabhu (2013) estimated the determinants of export service in India in their working paper "determinants of India service export" (No.33) from 1980-2011. By using annual time series data, the study highlighted the key indicators that play vital role India's service export sector, specifically, the empirical results showed that human capital development, infrastructure stock, manufacturing exports, exchange rate, foreign direct investment, financial development, world demand and institutions constituted aggregate determinants of service exports in India. However, while factors such as institutions, financial development, and foreign direct investment significantly influenced the modern service sector, traditional factors such as exchange rate, infrastructure stock, manufacturing exports and world demand have less impact on the traditional export service sector. Their working paper concludes that India service export should pay more attention to the supply side factors to improve both competitiveness and quantity of services exported.

Based on the above reviewed literature, it is empirical strong that the determinants of service exports are determined by the potential role of foreign direct investment (FDI), services and telecommunication facilities, real exchange rates, world income, human capital and the quality of domestic institutions. This study will try to empirically test some of these variables in the West African case.

\section{Source of Data and Methodology}

3.1. Data Source

The study used annual secondary data which were extracted from the world bank development indicators and United Nations Conference on Trade and Development (UNCTAD) for the empirical analysis (19902012). Due to unavailability of data on some indicators, the study limited the selection of variables to the following extrapolated pre implicit determinants.

\subsection{Justification and Description of Variables 3.2.1. World Income (WIC)}

The demand for export service increases with an increase in world income. That is the higher the foreign real-world income the higher service export demand by the rest of the world ceteris paribus. Most empirical literature suggest that the average long-term income elasticities are approximately more than one however, there exist a wide dilemma with regards to income elasticities. The measurement of world income has often varied across countries, however, generally, three income measures are used in the literature GNP, GDP or industrial production. In this study, GDP is used to represent the world income.

\subsubsection{Real Exchange Rate (EXH)}

The exchange rate measures the relative prices of service goods exported. It is the ratio of domestic price relative prices abroad. The real exchange rate is also a measure of actual competitiveness because it reflects the relative price, cost and productivity of a country relative to the rest of the world (UNCTAD, 2005). The decline in domestic relative prices due to the depreciation of the exchange rate indicates that the prices of exports of goods and services in the international market are cheaper and ultimately increase the demand for exports. We expect a positive or negative sign from this variable.

\subsubsection{Foreign Direct Investment (FDI)}

Foreign Direct Investment is a vital fibre in facilitating economic growth. Most development economist are of the view that Foreign Direct Investment (FDI) inflows are likely to promote economic growth in the 
recipient countries (De Mello, 1999) notwithstanding the above argument, FDI will only promote exports growth if it is directed towards helping and expanding domestic exports markets rather than just investing in peripheral sectors of the economy. So far, most of the empirical studies on the effect of FDI in promoting economic growth and service exports reported quite a mixed result. Some found FDI to have a positive impact on export performance of host countries (Eichengreen \& Gupta, 2012; UNCTAD, 2005).

\subsubsection{Communication Facilities (CMF)}

According to Caroline and Diana (2002) Internet development in a country can boost both trade in goods and services. In fact, communication facilities and infrastructure development are important determinants of service trade in among nations. Countries that export or import services naturally focus on the host country's communications infrastructure and facilities, such as mobile phone networks, telecommunications backbones, Internet speeds, postal network coverage, electricity, and the extent to which these services are made available to the average consumer. Shepherd and Wilson (2009) indicated in their study that bilateral trade flows are sensitive to information and communication technology (ICT). We expect a positive robust relationship between service exports and communication facilities. Due to unavailability of the data, the study used the number of fixed line users instead of Internet users.

\subsubsection{The Value Added by the Services Sector (VAD)}

The value added by services is a proxy for services production of a country. This implies that, the level of production determines the quantity exported (Bertil, 1968). Goods and service can only be exported if they are in surplus (after domestic consumptions) to the international market. With the growth of technology, we expect the value added in services to raise. The study of Majeed and Ahmad (2006) established the positive effect of value-added services on exports. In addition, since today's services have become tradable and potentially fragmented, a single service activity can be distributed and delivered around the world, and the added value of the service can increase export growth.

\subsection{Theoretical and Empirical Model}

In attempt to fully comprehend the determinants of trade, several scholars have relied on both classical and modern trade theories to explain these causal factors. However, most of these works focus much of their energy on trade in goods with only a handful of them dealing with trade in service. Another concern is whether traditional theories such as comparative advantage and Hecksher-Ohlin (H-O) framework, can also be applied to trade in service. Hindley and Smith (1984) and Deardorff (1985) wrote extensively on the application of these theories on trade in service as well. For trade in goods, most studies employed the gravity model to fundamentally assess their determinants. Nonetheless, for the sake of this study, we adopt the export demand function introduced by Bahmani-Oskooee (1986) with little additions and modifications of variables based on the reviewed literature. the aggregate world demand for a country's export is expressed in log linear form as:

$$
L n X_{t}=a+b L n W A_{t}+\theta L n \frac{X P}{X P W_{t}}+\gamma E_{t}+\varepsilon_{t}
$$

Where;

$\mathrm{X}=$ quantity of exports.

WA= weighted average of the real Gross National Product (GNP) of a country's trading partners.

$\mathrm{XP}=$ export price.

$\mathrm{XPW}=$ weighted average of the export prices of a country's trading partners.

$\mathrm{E}=$ export-weighted effective exchange rate.

Equation 1 indicates that at any given time, the demand of country's Y exports is influenced by foreign income, relative prices and the exchange rate. We further stretch Equation 1 to include other variables such as value added by services as a share of GDP, foreign direct investment and communication facilities.

$$
\operatorname{LnX} X_{t}=a+b L n W A_{t}+\theta L n \frac{X P}{X P W_{t}}+\gamma E_{t}+L n V A D_{t}+L n F D I_{t}+L n C M F_{t}+\varepsilon_{t}
$$

Equation 2 is express fully to incorporate all the study parameters as:

$$
\begin{aligned}
& \text { LnEXS } \\
& \text { Where; }
\end{aligned}
$$

$\mathrm{Ln}=$ natural $\log$.

$\beta_{1-} \beta_{5}=$ coefficients to be estimated.

$\varepsilon, a=$ represents error term and constant respectively.

EXS $=$ value of service export for country i at time $t$.

$\mathrm{EXH}=$ real exchange rate as a proxy for the relative prices in the domestic and international markets of country i at time t.

GDP = the real-world GDP value as a proxy of foreign income level.

$\mathrm{VAD}=$ the value added by the services sector as a percentage of GDP of country $\mathrm{i}$ at time $\mathrm{t}$.

FDI $=$ FDI as a percentage of GDP for country i at time $t$. 
$\mathrm{CMF}=$ communication facilities, represented by the number of fixed line users per 1000 people in country $\mathrm{i}$ at time $\mathrm{t}$.

\section{Results and Discussion}

\subsection{Descriptive Statistics}

In Table 1, the highest mean is 519.3606 and the smallest is -.4852167 which corresponds to exchange rate and communication facilities respectively. The minimum and maximum values which are -34.3513 and 8914.89 , is associated with only foreign direct investment. We are motivated that; these two variables will have a great impact on trade in service in the respective countries.

Table-1. Descriptive statistics.

\begin{tabular}{c|c|c|c|c|c}
\hline Variable & Obs & Mean & Std. dev. & Min & Max \\
\hline $\ln \mathrm{EXS}$ & 230 & 5.295626 & 1.228886 & 2.947172 & 8.152826 \\
\hline $\ln \mathrm{VAD}$ & 230 & 7.763178 & 1.413955 & 5.84814 & 12.34819 \\
\hline $\ln \mathrm{CMF}$ & 230 & -.4852167 & .8126772 & -2.156634 & 1.270389 \\
\hline $\ln \mathrm{GDP}$ & 230 & 22.26905 & 1.450711 & 19.57467 & 26.85313 \\
\hline FDI & 230 & 511.6021 & 1363.8 & -34.3513 & 8914.89 \\
\hline EXH & 230 & 519.3606 & 694.5834 & .0326156 & 4349.162 \\
\hline
\end{tabular}

The results of the correlation matrix of the determinants of export service in selected developing countries in West Africa is exhibited in Table 2, from the table, only exchange rate has negative correlation with export service while gross domestic product, value added, foreign direct investment and communication facilities possess positive correlation with international export service trade.

Table-2. Correlation matrix

\begin{tabular}{c|c|c|c|c|c|c}
\hline Variables & $\operatorname{lnEXS}$ & EXH & $\operatorname{lnGDP}$ & $\operatorname{lnVAD}$ & FDI & $\operatorname{lnCMF}$ \\
\hline $\operatorname{lnEXS}$ & 1.0000 & & & & & \\
\hline EXH & -0.3036 & 1.0000 & & & & \\
\hline $\ln \mathrm{GDP}$ & 0.8137 & -0.2180 & 1.0000 & & & \\
\hline $\ln \mathrm{VAD}$ & 0.8269 & -0.3279 & 0.9722 & 1.0000 & & \\
\hline FDI & 0.5639 & -0.1492 & 0.7279 & 0.7479 & 1.0000 & \\
\hline $\operatorname{lnCMF}$ & 0.2647 & -0.2127 & 0.0344 & 0.1286 & 0.0413 & 1.0000 \\
\hline
\end{tabular}

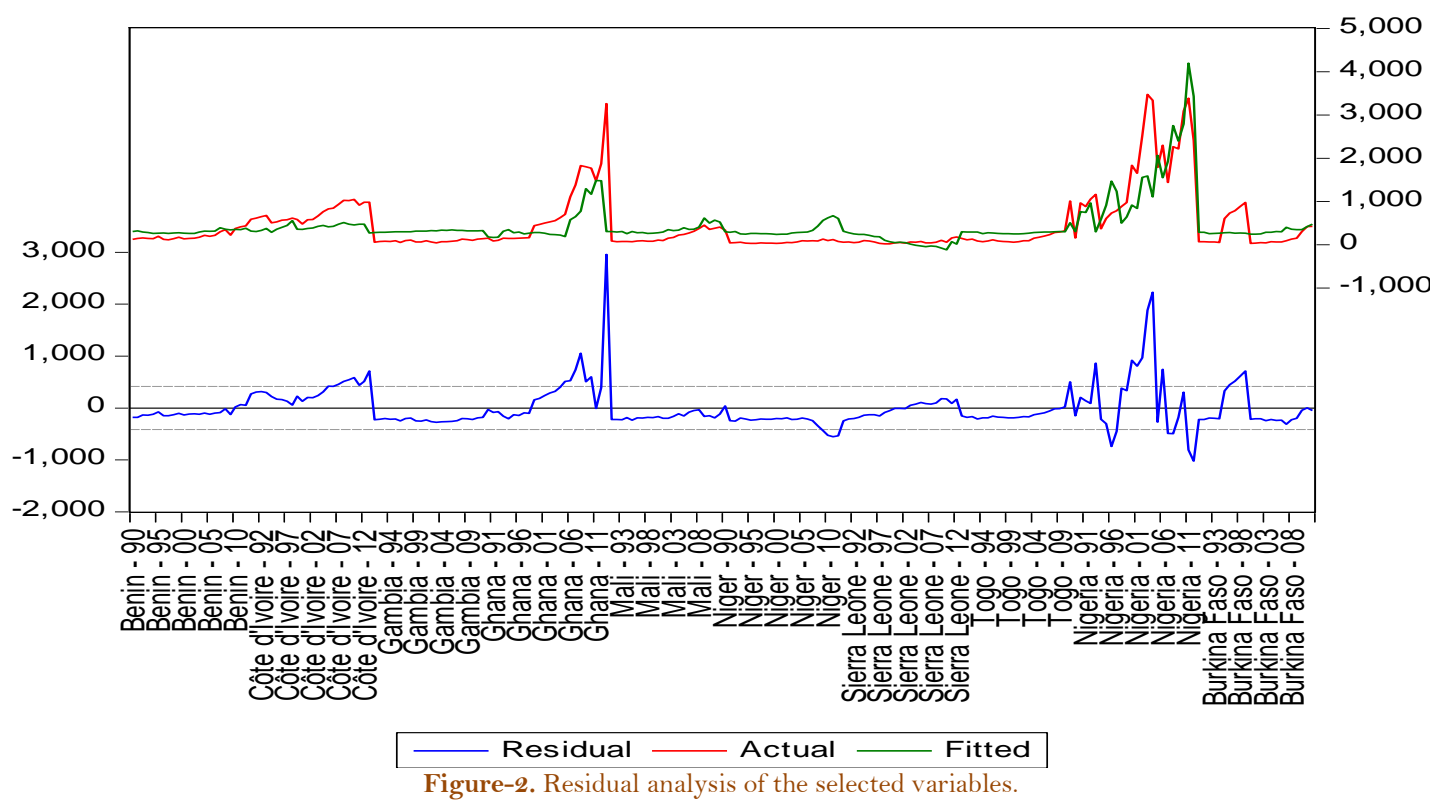

Figure 2 displays the residuals of the variables with respect to each country. This was carried out to ascertained how the data fits the model. The difference between the fitted value and the actual is the residuals. It's worth to note that the residual, actual and the fitted changes in the same direction but with slight deviation and volatility. The variables therefore have fairly and somewhat the same properties for the analysis. 


\subsection{Panel Diagnostic Test}

Based on the above analysis, the study carried out some panel diagnostic test to assess the verily and variability of the data structure as well as selecting the right criterion for estimations. The Breusch and Pagan Lagrangian Multiplier Test for Random Effects versus OLS and the Hausman test were estimated see Table 3 and Table 4 respectively.

Table 3 displays the Breusch and Pagan Lagrangian multiplier test for random effects vs pooled OLS technique. The standard deviation and variance of export service trade in the studied countries are 657.7476 and 432631.9 respectively. Based on the p-value, the study rejects the null and conclude that random effect is appropriate. There is evidence of significant differences across countries, therefore we cannot run a simple OLS regression.

\begin{tabular}{|c|c|c|}
\hline & Var & SD $=$ Sqrt (var) \\
\hline EXS & 432631.9 & 657.7476 \\
\hline $\mathrm{e}$ & 134365.9 & 366.5595 \\
\hline $\mathrm{u}$ & 37332.63 & 193.2165 \\
\hline Test: $\operatorname{Var}(\mathrm{u})$ & \multicolumn{2}{|l|}{$\mathrm{O}$} \\
\hline Chibar $^{2}$ (O1) & \multicolumn{2}{|l|}{56.59} \\
\hline Prob $>$ chibar $^{2}$ & \multicolumn{2}{|l|}{0.0000} \\
\hline
\end{tabular}

Table-4. Hausman test for fixed versus random effect models. Dependent variable LnEXS

\begin{tabular}{|c|c|c|c|c|}
\hline \multicolumn{5}{|c|}{---- Coefficients ---- } \\
\hline & (b) & (B) & $(b-B)$ & $\operatorname{Sqrt}\left(\operatorname{diag}\left(V_{-} \mathbf{b}-V_{-} \mathbf{B}\right)\right)$ \\
\hline & Fixed & Random & Difference & S.E. \\
\hline EXH & -.0002086 & -.0001148 & -.0000937 & .0000775 \\
\hline $\ln G D P$ & .8713612 & .5067232 & .3646381 & .2382737 \\
\hline $\ln \mathrm{VAD}$ & -.0389748 & .2223364 & -.2613112 & .223694 \\
\hline FDI & -.0000556 & -.00007 & .0000144 & .0000324 \\
\hline $\operatorname{lnCMF}$ & -.0451608 & .275671 & -.3208318 & .0931517 \\
\hline \multicolumn{5}{|c|}{$\begin{array}{l}\mathrm{b}=\text { consistent under Ho and Ha; obtained from } \mathrm{xtreg} \text {. } \\
\mathrm{B}=\text { inconsistent under Ha, efficient under Ho; obtained from xtreg. } \\
\text { Test: Ho: difference in coefficients not systematic. } \\
\text { chi2 }(4)=(\mathrm{b}-\mathrm{B})^{\prime}\left[\left(\mathrm{V}_{-} \mathrm{b}-\mathrm{V} \_\mathrm{B}\right)^{\wedge}(-1)\right](\mathrm{b}-\mathrm{B})=29.40 \\
\mathrm{P}>\text { chi2}=0.0000 \text {. }\end{array}$} \\
\hline
\end{tabular}

The results from Table 4 suggest that the fixed effect model is more efficient than the random effect model largely because, the $\mathrm{P}$-value of the $\mathrm{Chi}^{2}<5 \%$. We therefore fail to accept the null hypothesis and conclude that the fixed effect model is effective than random model. The fixed effect technique was therefore employed for the empirical estimations.

Table-5. Fixed effect model estimates

\begin{tabular}{|c|c|c|c|c|c|c|}
\hline $\operatorname{lnEXS}$ & Coef. & Std. err. & $t$ & $\mathbf{P}>|\mathbf{t}|$ & \multicolumn{2}{|c|}{ [95\% Conf. interval] } \\
\hline EXH & -.0002086 & .0001104 & -1.89 & $0.060^{*}$ & -.0004263 & $9.13 \mathrm{e}-06$ \\
\hline $\ln \mathrm{GDP}$ & .8713612 & .2881794 & 3.02 & $0.003^{* * *} *$ & .3033426 & 1.43938 \\
\hline $\operatorname{lnVAD}$ & -.0389748 & .2866061 & -0.14 & 0.892 & -.6038924 & .5259428 \\
\hline FDI & .7341176 & .1319213 & 5.56 & $0.000^{* * *} *$ & .4740996 & .9941355 \\
\hline $\ln \mathrm{CMF}$ & .4127865 & .1495308 & 2.76 & $0.022^{* * *}$ & .0745244 & .7510487 \\
\hline cons & -13.69133 & 4.537745 & -3.02 & $0.003^{* * *} *$ & -22.6355 & -4.74717 \\
\hline
\end{tabular}

Note: asterisk ***, ** and $*$ means significance at $1 \%, 5 \%$ and $10 \%$ levels respectively

R-Sq: $\{$ within $=0.3089$, between $=0.8532$, overall $=0.6655), \mathrm{F}(5,215)=19.22$, Prob $>\mathrm{F}=0.0000$.

From the fixed effect analysis, real exchange rate, communication facilities, foreign direct investment and gross domestic product were statistically significant at $10 \%, 5 \%, 1 \%$ respectively. All the significant dependent variables exhibit positive relationship with export service except real exchange rate. The negative sign attached the coefficient of exchange rate is explained as an appreciation of currency. An appreciation of the individual country currencies will boost export service by its corresponding coefficient value. However, a depreciation would have been much appropriate since it makes domestic export service cheap in the international markets.

Foreign income level is the representative of the world's gross domestic product (GDP) and one of the key factors determining service exports. The survey results showed that GDP has a significant impact on service exports, with each increase of $1 \%$ in GDP will lead to $0.87 \%$ increase in service exports. Higher GDP means that trading partners or importing countries have higher potential demand for service exports. At the same time, it provides the country with the opportunity to export its services as an intermediate input for other 
sectors of the economy such as banking sector, communication sector, agricultural sector and mining industries. This finding is in line with Khedhiri and Bouazizi (2007) and Siti et al. (2017).

As for foreign direct investment, the positive and robust relationship is consistent with the studies of Siti et al. (2017) and Ahmadzadeh, Knerr, Yavari, Asari, and Sahabi (2012). These studies demonstrated that some components of trade in services, such as education, banking and insurance, are best carried out through foreign direct investment.

Likewise, communication facilities are important as one of the determinants of service exports since the nature of export services is versatile and are intangible and heterogeneous and serves as an intermediate and sometimes a finished input to foreign manufacturers. This discovery demonstrates that communication facilities have a significant impact on service exports. This finding is consistent with the results of Majeed and Ahmad (2006).

\section{Conclusion Remarks}

This study empirically investigated the determinants of export service in selected developing countries in West Africa (Ghana, Benin, Côte d'Ivoire, Gambia, Mali, Niger, Sierra Leone, Togo, Nigeria and Burkina Faso). The study adopted the export demand function introduced by Bahmani-Oskooee (1986) with little additions and modifications of variables based on the reviewed literature. A linear penal data of ten West African countries were sourced from the World Bank development indicators and United Nations Conference on Trade and Development for the analysis. It was discovered from the empirical results that the value added by the services has no impact on service export in the selected countries. However, variables such as foreign direct investment, communication facilities, real exchange rate, and gross domestic product were discovered to have a significant robust impact on export trade in services. Foreign income which is proxied as GDP has a positive impact on demand for service exports, suggesting that exports can be regarded as an engine of growth for these developing West African nations. Again, the positive sign of foreign direct investment implies that these countries can relied on FDI and multi-national companies (MNCs) to change their economies from those of primary commodity suppliers to those of industrial nations by financing service exports and adding value to them. Nevertheless, the robust coefficient of the communication facilities further propose that these economies should channel resources towards them so as to have a sufficient and efficient physical communication infrastructure to support the methods of service distributions and export.

These countries should therefore widen their opportunities to strive in exporting services worldwide. This can be materialized by exploiting their potentials with relative competitiveness and reasonable negotiations in the global export market.

\section{References}

Africa Competitiveness Report. (2015). World economic forum. Retrieved from http://reports.weforum.org/africacompetitiveness-report-2015/. [Accessed, June,10, 2019].

Ahmadzadeh, K., Knerr, B., Yavari, K., Ásari, A., \& Sahabi, B. (2012). Competitiveness and factors affecting in services export. Journal of Basic and Applied Scientific Research, 2(10), 10793-10802.

Alege, P. O., \& Ogundipe, A. A. (2015). The role of services trade in economic development. British Journal of Economics, Management \& Trade, 5(3), 350-365.

Anderson, J. E., \& Eric, v. W. (2003). Gravity with Gravitas: A solution to the border puzzle. American Economic Revierw, 93(1), 170-192. Available at: 10.1257/000282803321455214.

Bahmani-Oskooee, M. (1986). Determinants of international trade flows: The case of developing countries. Journal of Development Economics, 20(1), 107-123.

Barry, E., Park, D., \& Shin, K. (2012). When fast-growing economies slow down: International evidence and implications for China. Asian Economic Papers, MIT Press, 11(1), 42-87.

Bertil, O. (1968). Model construction in international trade theory. In W. A. Eltis, M. FG., Scott \& J. N. Wolfe (Eds.), Induction, Growth and Trade (pp. 325-341). Oxford: Clarendon Press.

Brandicourt, V., Schwellnus, C., \& Woerz, J. (2008). Austria's potential for trade in services: FIW Research Reports.

Caroline, F., \& Diana, W. (2002). The internet and international trade in services. American Economic Revierw, 92(2), 236240. Available at: 10.1257/000282802320189320.

Copeland, B., \& Mattoo, A. (2008). The basic economics of services trade. In A. Mattoo, R. M. Stern, \& G. Zanini (Eds.), A Handbook of International Trade in Services (pp. 84-129). New York: Oxford University Press.

Dash, R. K., \& Parida, P. C. (2013). FDI, services trade and economic growth in India: Empirical evidence on causal link. Empirical Economics, 45(1), 217-238.

De Mello, L. (1999). Foreign direct investment-led growth: evidence from time series and panel data. Oxford Economic Papers, 51, 133-151. Available at: https://doi.org/10.1093/oep/51.1.133.

Deardorff, A. (1985). Comparative advantage and international trade and investment in services. In R. M. Stern (Eds.), Trade and Investment in Services: Canada/US Perspectives (pp. 39-71). Toronto: Ontario Economic Council. Developments in International Trade in Services, Paris.

Eichengreen, B., \& Gupta, P. (2012). Exports of service: Indian experience and perspective. Indian Growth and Development Revier, 6(1), 35-60.

Francois, J., Hoekman, B., \& Woerz, J. (2007). Does gravity apply to intangibles? Measuring barriers to trade in services. Paper presented at the at the CEPII-OECD Workshop Recent Developments in International Trade in Services, Paris, November. 
Frankel, J. A., \& Romer, D. H. (1999). Does trade cause growth? American Economic Review, 89(3), 379-399. Available at: https://doi.org/10.1257/aer.89.3.379.

Freund, C., \& Weinhold, D. (2004). The effect of the Internet on international trade. Journal of International Economics, 62(1), 171-189.

Grunfeld, L. A., \& Moxnes, A. (2003). The intangible globalization: Explaining the patterns of international trade in services. Norwegian Institute of International Affairs, No. 657.

Hindley, B., \& Smith, A. (1984). Comparative advantage and trade in services. The World Economy, 7(4), 369-390.

Hoekman, B. (1996). Assessing the general agreement on trade in services. The Uruguay Round and the Developing Countries, 996(1), 89-90.

John, M. (1995). National borders matter: Canada-U.S. Regional trade patterns. American Economic Review, 85(3), 615-623.

Khedhiri, S., \& Bouazizi, T. (2007). An empirical analysis of the demand elasticity for Tunisian exports. Applied Econometrics and International Development, 7(1), 134-148.

Kimura, F., \& Lee, H. (2004). The gravity equation in international trade in services.

Lorde, T., Francis, B., \& Drakes, L. (2011). Tourism services exports and economic growth in Barbados. The International Trade Journal, 25(2), 205-232.

Majeed, M. T., \& Ahmad, E. (2006). Determinants of exports in developing countries. The Pakistan Development Revierw, 45(4 Part ii), 1265-1276.

Mattoo, A., \& Stern, R. M. (2007). Handbook of international trade in service. New York: United States by Oxford University Press Inc.

Organization for Economic Co-operation and Development (OECD). (2002). Retrieved from www.oecd.org. [Accessed, June, 3, 2019].

Pravakar, S., Ranjan, K. D., \& Prabhu, P. M. (2013). Determinants of India's service exports. IEG Working Paper No. 33.

Qasenivalu, M. T. (2008). The role and impact of services sector on economic growth: An econometric investigation of tourism and air services in Fiji (1968-2006). Unpublished Master's Thesis. Massey University, Palmerston North, New Zealand.

Sandeep, K. (2011). Determinants of export services of USA with its Asian partners: A panel data analysis. Eurasian Journal of Business and Economics, 4(8), 101-117.

Shepherd, B., \& Wilson, J. S. (2009). Trade facilitation in ASEAN member countries: measuring progress and assessing priorities. Policy Research Working Paper Series, No. 4615.

Siti, A. A., Shivee, R. K., \& Normaz, W. I. (2017). Determinants of service export in selected developing Asian countries. International Journal of Business and Society, 18(1), 113-132.

UNCTAD. (2005). World investment report. Paper presented at the Geneva: United Nations Conference on Trade and Development.

UNCTAD. (2014). Statistical database online. Geneva, Switzerland: UNCTAD.

World Trade Organization (WTO). (2014). Retrieved from https://www.wto.org/from https://www.wto.org. [Accessed, June, 3, 2019.

WTO. (2010). World trade annual report 2010: Trade in service (pp. 48). Geneva: WTO. 